\title{
IMAGE AND NATION BRAND FORMATION AS TOURISM DEVELOPMENT FACTOR IN KAZAKHSTAN
}

\section{Ziada Borbasova}

Research Institute of New Economics and the System Analysis at KEUK, Karaganda, Kazakhstan

\section{Sairan Ulakov}

Karaganda Economic University, Karaganda, Kazakhstan

\section{Yuri Ossik}

Russian Academy of Natural Sciences, Karaganda Economic University, Karaganda, Kazakhstan

CMESTE

JEL Category: L83, Q13, Z33

\begin{abstract}
The role of marketing in shaping the image and creating a national brand of the country as a factor in the development of tourism in Kazakhstan. This article discusses the marketing approach to image formation, creation and promotion of a brand of Kazakhstan as a national idea. The theoretical substantiation of necessity for using marketing tools is given as a form of the country's image for developing tourism and territory. The authors, recognizing the importance of a single national brand of the country, at the same time warned that the creation and promotion it must be seen as a long process, as opposed to those opinions. Interesting and worthy of attention, those who are directly responsible for the formation of the image, creating and promoting the country's brand, is the example of Germany in solving this problem, which is used in preparation for the World Cup in 2006. This approach is possible, according to the authors, in preparation for the Expo-2017 and Universiade-2017 and proposals are given to apply similar marketing tools to enhance the image of Kazakhstan.
\end{abstract}

Keywords: marketing, image, branding, brand of the country, the German experience, brand positioning Kazakhstan EXPO-2017, the energy of the future, Tourism.

1 SYMBOLS AND BRANDS IN CONSCIOUSNESS AND BEHAVIOR OF THE MODERN CONSUMER

Address of the corresponding author:

Ziaida Borbasova

玤 borbasova@mail.ru
The phenomenon of consumer consciousness has already been the focus of special humanitarian and applied research for a long time. 
At that along with material well-being growth a symbolic aspect of consumerism is emphasized still oftener. R. Barthes, J. Baudrillard, F. Jameson, P. Bourdieu, M. Foucault and other competent authors analyzed a semiotic character of consumer relations from different methodological viewpoints. Baudrillard concept seems the most consistent among all concepts. Beginning from sketchy the system of objects, and concluding with the creation period of, for a critique of the political economy, of the sign, Baudrillard strictly adhered to the same theorem of consumerism: "Consumption, as much as this word actually means, is the activity of a systematic manipulation of signs" (Baudrillard, 2001, p. 92).

From this viewpoint, consumerism is reduced not to consumption of things or services proper, but only of content mediated by them (for example, social status). The goods become an element of some peculiar symbolic constructor.

The important psychological factor, defining the relation to the goods, is the brand. According to David Olgvy, the brand is an intangible sum of properties of a product, service or firm. (Initially in America a brand - incandescent iron for marking cows within a herd and a brand itself on cattle croup or ear) (Posypanova, 2012).

Earlier it was considered, that the brand is a synonym of a famous trademark. In modern consumption, the brand can be the goods, service, company, possessing of psychological resources (value), but neither its trademark (brand name), nor the set of ideas about it (associations of a brand or a brand myth), nor the system of ideas, images about it (brand image). The brand meaning is given in the dictionary of economic terms: the world-famous trademark; the product protected legislatively; the company (its name) or the concept separated from a lot of the same kind by public consciousness.

The theme of our research relates to a collective, complex brand - a brand of places and of a country as a whole. About these brands, there are much fewer publications than about brands of products, services, and firms although the interrelation between the first and the second exists and it is rather a complex one.

\section{FROM BRANDING OF THE GOODS AND SERVICES THROUGH PLACE BRANDING TOWARDS COUNTRY BRANDING}

For successful participation of Kazakhstan in competition among countries, and also for its effective integration into world economic area, one needs research and development of its competitive advantages, including - of branding and image nature. The country image is formed not only by means of popularization and purposeful distribution of the positive information about products services and firms but also is based on all sides of social life and economy of separate territories and countries.

Place branding in many developed countries has become one of efficient tools of their territory (city, region, country) development. In the CIS countries, place branding principles started to be used rather recently where the concept proper has just begun to be included into a system of marketing of these countries, the Given method assumes planning and territory development as single integral investment or tourist object. Thus, place brand - set of well-established images, opinions, events, products and services, associated by target audiences with a definite territory, and in total - with a country. This image can be unified (if constituent brands of places, individual companies and organizations harmonize with each other) or fragmented (if a country is torn apart by contradictions - ethnic, political, cultural and language, etc.).

The integral country brand is made up of a great number of components: political or public figures of the given state, separate areas of its vital activity - power, economy, army, foreign and domestic policies, culture, outstanding figures etc. It is that that defines reputation the state gets or will get in the consciousness of world community because of interactions of either of its subjects (territories) with the rest of the world. Therefore, the country brand is a cumulative indicator of authority and success of its actions on international stage, opinion estimation of the foreign public about a country. Today it is already acknowledged, that programs of creation and promotion of a brand, formation of a country image in the modern world it is possible and it is 
necessary to carry out with the use of marketing tools.

When comparing present time with the time of independence of Kazakhstan beginning, citizens of our republic see the enormous positive changes, a new image of the country constructed the worthy present and resolutely directed to uneasy globalized future. And do other world countries know this renewed rapidly developing Kazakhstan? Or do many of them still associate our republic with agrarian and raw material backwardness and mainly culture of nomadic shepherds? Even not all citizens of Kazakhstan notice and adequately estimate dramatic changes of successful entry of the country in global social and economic community, in the Eurasian and world culture. Our rich and glorious history, our present outstanding successes we report insufficiently about to world community, we work insufficiently on the creation of brands of Kazakhstan territories and the country as a whole.

One of the reasons of delay use of areas branding - unwillingness to apply marketing principles, as it demands transition from "object" method (remained after the planned economy) to marketing one - "territorial". Certainly, and using "object" approach to development strategies were worked out considering attraction of investments and tourists. However, they have been aimed only at certain objects. At such approach, the investor or the tourist sees one or several objects, but by no means a territory (country, region) with all its advantages, amenities, possibilities, and potential.

Place marketing assumes its development as unified investment or tourist object, with all its potential for investment, business, and tourism. All attractive objects of investment and tourism, are promoted together (under an umbrella) with a territory itself, as its part. And the most important thing, they consider not only tangible assets (bowels, combines and sports complexes and other industrial and residential funds), but also intangible assets - personnel potential, advantageous geographical location, unique climatic features, mentality, rich historical heritage, varied and original cuisine, language, interesting traditions and customs and so on. Investors, tourists, and business see the whole territory as a single unique living organism where it is possible to invest in and to spend time with interest. In the set of all these constituents, the territory takes definite outlines clear for the target audience, i.e. an image, and so country brand. Thus, a brand of places merges in an integral image - country brand. And the country brand can be used successfully in the development of the whole territory and its tourist places.

What to begin brand creation with? Many people reduce everything to draw a logo and to think up a slogan for a region. The falsity of such an approach was proved by well-known scientists Simon Anholt, Philip Kotler, Donald Haider, Irving Rein who have brought an essential contribution to the solution of a problem of the study of places branding. As far back as in 1993 since the publication of the book "Marketing Places: Attracting Investment, Industry, and Tourism to Cities, States, and Nations" (Kotler, Haider, \& Rein, 2002) there has been a concept, that in the modern world citizens become consumers, and territories (cities, regions, and countries) products (Ashworth \& Kavaratzis, 2010). In 2002 $\mathrm{S}$. Anholt, one of leading world experts in branding area has used "places branding" phrase as a term for the first time. According to Anholt's theory (hexagon), there are six elements of a modern pace brand: tourism, export brands, policy, business and investments, culture, people (Anholt S. , 2008) (Anholt S. , 2007). Only based on an optimum combination of all hexagon corners, it is possible to become successful in the branding of country territory (Kudasheva, 2013). The "place brand" phrase that was perceived in Kazakhstan several years ago, as something new, fashionable and hard to understand, nowadays becomes widely used among representatives of the tourist industry and bodies of the state and regional authorities. In recent years, tourism branch problems are in the focus of attention of the Government of the RK. So, in the country "Development of tourist branch of the Republic of Kazakhstan for 2011-2014" target program has been approved and is being carried out.

They address to branding at times not because there is an urgent need for it, and according to "we want to have a brand too" principle. Hence, in our opinion, errors, disappointments and following negation of branding as a marketing tool. Here the relation to the idea of brand as a reflexion of ambitions and aspiration to bombast manifests itself. One should remember that branding is by no 
means reduced to the formulating of brand idea. The idea is the second step, and the first one is the marketing analysis of preferences of citizens and foreign tourists and is also the competitive environment research. Creation of successful tourist brand is work for years ahead in an information, infrastructural and legislative area, and in personnel training sphere. A lot of people think, that it is necessary to select such a slogan (symbol, logo, event) which will speak for itself, the rest is allegedly details, unacceptable. Even local, world famous brands, such as Oxford, New York, Paris etc., have emerged not as a result of special brand campaigns and were naturally formed throughout centuries.

If to speak about Kazakhstan then quite often catchy slogans, as a rule, are not supported by any unique specific offer for the tourist; there is no popular, practically applicable territory image and understanding what exactly the tourist will get by visiting a positioned place and what one should expect from the given destination. Examples: "Burabay - the second Switzerland"; "Astana - the heart of Kazakhstan"; "Almaty - southern capital"; "Kazakhstan - the heart of Eurasia" etc. The geographical associating is good if a geographical object possesses exclusive tourist fame and clear advantages to the visitor, however, if it has no unique properties and characteristics known to the public at large it will be just one of many. Here it is possible to speak only about the addition to a ready territory image, but not about its creation and orientation to this uniqueness. To integrate a territory into the "talked-up" routes does not always help. Because at failure of such integration - attempt to create own twin brand, as a result can turn into endless chain of very look alike museums, mosques, landscapes and finally cities (for example, cities on the Silk Way), regardless on territory of what country they are situated either in Uzbekistan or in Kazakhstan. An example of such an approach for us if not to make corresponding marketing decisions, there even can be such an international project of Turkic languages countries on the creation of mutual "Modern Silk way" project where Kazakhstan will become a coordinator (Kuryatov, 2014).

Traditionally the state occupies itself with the problem of formation of a national image, nationwide brand in all countries of the world. Experts agree about opinion, that always the customer and the initiator of the new national idea in Kazakhstan is ambitious and charismatic leader being in power since the first days of independence of Kazakhstan - the President of Republic - the Leader of the nation N.A. Nazarbaev. Many of known events of universal importance took place in Kazakhstan mostly thanks to the main newsmaker of the country Nazarbaev N.A., to his exclusive gift to put forward creative and ambitious ideas in creation and realization of event measures, in working out of strategic programs on the development of either aspect of the state. So, the President of Kazakhstan is sure, that in the economic aspect we may become the bridge connecting advanced economies of the European Union (on the one hand), and dynamical fastgrowing economies of East, Southeast and South Asia (on the other hand). If to look at it more broadly, then he as the advocate Eurasianism, has made to all CIS countries the unique offer - to create a large economic area in the center of Eurasia as an area of mutual development embodied in the form of the Eurasian Economic Union (EAEU). Therefore, it is no coincidence that national brand promotion becomes an economic direction. As the beginning of the given campaign was the message of the President of the Republic of Kazakhstan of N. Nazarbayev to the people of Kazakhstan in 2006 called "Strategy of Kazakhstan entry among 50 most competitive countries of the world". The given message had program nature for the whole PR-strategy of Kazakhstan in an economic direction and in it key priorities of the positioning of Kazakhstan in the world market are sorted out (Nazarbayev, 2006) (Nazarbayev N. , 2012). They were continued and corroborated in the subsequent annual messages of the President of the country to the Kazakhstan people (and to the world as a whole), in particular in 2013 and 2014.

So in the state policy, the basic value has developed - to play the important role in social and political events of the Eurasian area. Kazakhstan, due to its geographical position - on Europe and Asia junction, is some kind of crossroad of the worlds, combining cultural values of these parts of the world within itself. In Kazakhstan two world religions - Islam and Christianity became closely intertwined, more than 100 nationalities live well. The strategic transport ways lay across the country territory connecting Asia with Europe, 
Russia with the countries of the Central Asia. And accordingly, through Kazakhstan "path" of migration flows bearing a part of the culture of various people and settling in this country in some way or another (the Silk Way continues) was made. The Kazakh people themselves nowadays absorb the best values of the western culture. Especially it is pronouncedly remarked among inhabitants of cities and youth, its wishes to accept and live according to the values of the West freedom and emancipation. Thereby the Kazakh people, its majority still remaining in eastern mentality without losing contact with origins, with collectivism and unity of the East (China, Korea, Malaysia, Japan), also want to live according to the best European values.

Country image, by definition of the World Tourism organization, is a set of emotional and rational ideas following from comparison of all country signs, one's own experience, and rumors influencing the creation of a certain image. All listed factors allow, at the mention of the name, at once to make the whole chain of associations in relation to the given country. How to ensure a positive country image? Opinions of politicians are not much different in this respect. The president of Kazakhstan N. Nazarbayev as, the leader of one of the independent countries appeared not so long ago on a world map, has defined following major factors of his republic appeal: political stability, friendly relations with neighbors, a high degree of market economy development together with efficient state regulation.

Thus, the positive authority of Kazakhstan and in particular its leader - the President of Kazakhstan N.A. Nazarbaev, on the one hand, deserves working out and the creation of brand corresponding to high country authority on a global scene and to a worthy standard of living of Kazakhstan citizens. On the other hand, there is an urgent need in it for the creation of an image of the appeal of the country and its people for visitors, tourists and all world community.

Adoption and carrying out of the long-term national "Brand of Kazakhstan" program will help not only to form recognizable positive image of the country in the world, but also will promote emergence of Kazakhstani national identity, mutual sense of goal and national pride that will help to unite Kazakhstan around the single national idea - economic country development (entry of Kazakhstan in among 30 developed countries of the world). As we have already mentioned, this process is very long and it is not limited by some timeframe to achieve the aim. Therefore, image formation should be carried out by a sequence of continuous events directed on its improvement and positioning of the country in the world.

Preparation and carrying out of two important international events - the Winter University Games in Almaty and EXPO - 2017 "Energy of the future" exhibition may become the important events favoring creation and positioning of the brand of Kazakhstan. They will be a starting point which will allow Kazakhstan to promote its brand and to form image not only as the country being in the heart of Eurasia, and as an innovative and ambitious country constantly aspiring to adoption of new technologies, the country with strong scientific potential directed in the future (Nazarbaev university and colleges of world level in Astana and Almaty, Nazarbaev intellectual schools all over the country, etc.); the country where there are all conditions for those who is ready to invest capital which will be reliably protected and will work for the mutual benefit.

\section{GERMANY EXPERIENCE TO CARRY OUT IMAGE CAMPAIGNS}

Creation of country brand - cause of all its inhabitants, beginning from the head of state and concluding with an average citizen. In our opinion, the experience of Germany can be as an example how to carry out image campaigns on the eve of forthcoming significant world events in Kazakhstan in 2017.

It is well known that in German culture soccer occupies a special niche and is a part of a daily life of people. Therefore, among a huge number of campaigns directed on the formation of Germany image, none of them can be compared with a campaign to strengthen the national brand that begun in 2004 within the frameworks of preparation for World Cup 2006.

Everything has begun with awareness by the higher political persons of Germany, that the country is getting the negative image owing to increase of unemployment rate and slow rates of economic growth. To change the situation which 
threatened outflow of highly skilled specialists and decline of macroeconomic indicators, they required campaign that would show Germany as an innovative and ambitious country where there were all conditions for life and capital investments.

For the first time the central idea of future image campaign was voiced during an inaugural speech of the President of Federative Republic of Germany Horst Koehler who mentioned that Germany - Land of Ideas, encouraging experiments and inquisitiveness; courage, creativity and wish to create something new, without forgetting former achievements. Potentially considerable social and economic effects from planned image events have led to the consolidation of the state and society under the patronage of the President of Germany (n.d., 2016). Official campaign sponsors were the Government of Germany represented by the Ministry of Economy and Technologies, the Ministry of Foreign Affairs, the Ministry of Education and Research, and also the Federal Union of the German Industry (BDI). The initiative to change Germany image caused state-private partnership concerning PR measures. To coordinate and carry out measures the coalition of the largest companies in the country created " $F C$ Deutschland" legal person composed of 23 companies including world famous - Deutsche Bank, Audi, T-Mobile, Lufthansa. The estimated image campaign budget was $€ 20$ million, of which 10 million was given by the federal government and 10 million - BDI (n.d., 2016). Campaign working out has begun in 2004, and in the middle of 2005 (on June, 14) Minister for Internal Affairs Otto Schily and BDI vice-president made a presentation of "Germany - Land of Ideas" campaign. The key idea of the given image campaign, according to developers' opinion - the given phrase combining positive features of Germany within the country and abroad: science and culture nation, the country of poets and thinkers, innovation products with "made in Germany" brand. The central idea embodies the quality Germany is valued for all over the world: inventiveness and creative passion, perfect quality.

To inform address groups of the central idea they began to carry out five developed projects mainly in 2004 because Germany got the right to hold the World Cup. They considered that sporting event of such kind draws a huge public response, attracts media attention, promotes inflow of tourists and enables the country to show its achievements.

On the threshold of 2006 image campaign launch in a few large cities of the world - in the USA, in France, in the Great Britain, in Japan - they installed TV screens showing shots from "Germany - Land of ideas" film specially prepared for this instance. To provide media support of special five projects in August 2005 on http://www.land-of-ideas.org/ campaign site they created "Media Service" which was a unique information resource for 15 thousand journalists who were going to visit Germany in 2006 to cover the World Cup. The given resource provided audio/video/text data on Germany and the image campaign; on the possibility to establish various contacts; data, where matches take place and any information about Germany, selected considering interests and country of person interested.

In 2005 there were large image events, mostly directed to work with mass media to inform address groups of the information on the campaign beginning which helped to understand their point more deeply. We believe they are very important for the understanding of their orientation and we give them in chronological order:

- June 14, 2005, "Germany - Land of Ideas" campaign and its six projects were presented.

- August 26, 2005, "Germany - Land of Ideas" campaign becomes the official partner of the 2006 FEI World Equestrian Games.

- September 13, 2005, the international presentation of the campaign and the second project "Welcome to Germany - Land of Ideas".

- October 3, 2005, on Germany Unity Day (Tag der Deutschen Einheit) Brandenburg becomes a partner of the campaign and on the same day "Germany - Land of Ideas" campaign fan club was formed. The fan club aims to encourage a sense of belonging to people to Germany and the carried-out campaign and to favor meetings of people who are optimistic, love their country and aim for the future.

- October 27, 2005, organizers of the campaign declared there would be a tour from November $1^{\text {st }}$ until December $31^{\text {st }}$ through 12 cities where matches would take place. The 
tour purpose - to give the chance to people to feel involved in the World Cup organization. During visiting of cities, they plan to hold sporting events and games, and also enroll new fan club members.

- December 5, 2005, the announcement of 365 participants of the third project " 365 Landmarks in Land of Ideas".

- December 6, 2005, the international presentation of media service for journalists on a campaign site where till 2006 spring they planned to prepare collections of materials for journalists from 40 countries and to grant access to 1000 articles and photos too.

- December 22, 2005, presentation of prototypes of sculptures for "Walk of Ideas" project.

- December 29, 2005, opening of the World Cup year in Germany. On the square in front of the Brandenburg gates in Berlin representatives of each of the countries, taking part in the World Cup, are welcomed by the Minister for Internal Affairs of the Federative Republic of Germany and the mayor of Berlin.

The opening ceremony of the World Cup year "Welcome to Germany - Land of Ideas" was broadcast on 300 channels.

Events within image campaign frameworks that had taken place from June 2005 until January 2006 resulted in an unprecedented response of mass media. For the given period in print media, on TV and on the Internet there had emerged about 7143 messages about the campaign which reached about 471 million people. About 40 thousand people became the fan club members, about 55 thousand copies of the guide to the Land of Ideas. About thousand international journalists made use of materials of "MediaService" information resource on the campaign site

In 2006 they began to carry out five main projects on this basis:

1. project: "Welcome to Germany - Land of Ideas". Project realization has begun on October 3, 2005, on Germany Unity Day. 226 embassies and consulates received collections of materials about Germany and the image campaign to distribute among visitors; all visitors of the country were welcomed at the airports, cities, and stations.
There was "Germany - Land of Ideas" campaign presentation during all celebrations in honor of Germany Unity in embassies.

2. project: " 365 Landmarks in the Land of Ideas". Project realization has begun in 2005. Every year in Germany there is national competition among companies, research, cultural and fine arts institutes. The jury consisting of 18 persons chooses 365 innovative ideas which will be presented every day from January $1^{\text {st }}$ until December 31 $1^{\text {st }}$. After all, ideas have been presented winners in 7 categories are chosen. (Competition of 365 winners began to be held annually since then, it attracts a lot of public attention as participants present their ideas in all corners of Germany). The monthly campaign newsletter regularly covers competition events. Following the results of the competition they publish a book containing data about all winners that allows potential investors to familiarize with their ideas.

3. project: "Walk of Ideas". The project was carried out from March till May 2005. During this time in different areas of Berlin they installed six huge sculptures, symbolizing wealth of ideas and inventive spirit of Germany. Sculptures reflect inventions and discoveries of the German people that continue to produce a considerable effect on science, culture, and technologies. Installation of each figure was accompanied by mass media attention mainly owing to the project sum (to create each sculpture they spent from 300 till $350 \mathrm{~K}$ euros) and due to their installation in the most populous city places.

"Innovative football boots" was the first sculpture to be installed, reflecting the fact that the first football boots, allowing standing firmly on a wet and swampy football pitch brought to the victory of Germany in the World Cup in 1954, had been created by German Adi Dassler, who established Adidas company.

The second sculpture in the form of a huge pill is called "Milestones in medicine". It tells that the most popular analgesic pill in the world was invented in Germany by Bayer company; German researchers Felix Hoffmann, Robert Koch, Emil von Behring, Paul Ehrlich and Gerhard Domagk contributed a lot to medicine development; cardiac catheter and X-ray 
apparatus were created in Germany. And nowadays German scientists develop about 300 new medicines, including anticancer vaccine, one for the treatment of heart beats, diabetes, and Alzheimer's disease.

The third sculpture - "Automobile" was installed near the Brandenburg gates. It reflects successes of Germany automobile production: the whole world uses motors named in honor of Germans Otto and Diesel; such German makes as Audi, BMW, Mercedes-Benz, Opel, Porsche, and Volkswagen enjoy wide popularity; thanks to Germany cars got airbags, ABS, ESP, fourwheel drive, etc.

The fourth sculpture - "Modern printing", reflecting the fact that due to the printing press invention by Gutenberg mass distribution of the first best seller the Bible became possible that in turn accelerated processes of the Reformation and the Enlightenment. Germany gave to the world great writers and thinkers Goethe, Schiller, Mann, Grimm Brothers, etc.

The fifth sculpture - "Musical masterpieces", emphasizes the huge contribution of German composers to the creation of world famous music masterpieces - Mendelssohn's Wedding March, Beethoven's symphonies, Schumann's etudes, Bach's toccatas and Wagner's "Flight of Valkyrie".

The last sculpture - "Relativity theory" tells about creation by German Albert Einstein of the relativity theory that led to the development of quantum mechanics and lasers Theodor Hansch who in 2005 received the Nobel Prize in Physics.

"Walk of Ideas" project was one of the most successful ones in the image campaign since creatively executed sculptures drew the huge attention of journalists, population and tourists.

4. project: "100 Masterminds of Tomorrow" became a logical conclusion of "Walk of Ideas". Specially formed jury selected 100 persons who got considerable results in economics, science, art, etc. Within the frameworks of the given project, they organized an exhibition where there were fulllength photos biography and ideas of the selected 100 people. These people will have to form the future of Germany based on successes of past generations shown in the form of sculptures on "Walk of Ideas".

5. project: investment image promotion. Germany Trade and Invest and "Germany Land of Ideas" campaign developed "Invest into Germany - Land of Ideas" program which goal - to improve Germany image as an ideal place to do business, using the emotional address to potential investors. The single central idea for all five projects meant to convince investors that all put forward ideas is successfully implemented in Germany.

6. the project also includes 10 subprojects, beginning from the distribution of information booklets about Germany investment possibilities, conducting forums and concluding with one of the most unusual advertising campaigns with the participation of German model Claudia Schiffer. The ad campaign consisted of putting up 11 posters with the model in the financial centers of London, Tokyo, New York. The first posters were displayed in London from June 5 till July 2, 2006, in Tokyo posters were displayed from June 26 till July 9. The campaign ended in New York where from 1 till 30 July at the Big Central Stadium 80 posters were put up. Before posters were put up press conferences were held in German embassies in each of the cities. The ad campaign was a great success which was proved by placing of one of the posters with Claudia Schiffer in the Advertising Museum in Paris.

Advertising campaign singularity consisted in that that posters appealed not to reason of potential investors, and to their emotions and sexual instincts. Each poster slogan was deliberately ambiguous because of the model covered only with the flag of Germany. For each city, they selected different posters: more conservative ones for London and Tokyo, and with sexual context for New York.

Other slogans on this poster: "Follow your instincts. Invest in Germany"; "Invest in Germany, boys"; "Get your hands on a German supermodel". Another slogan on a poster for Grand Central Station (New York): "Grand ideas in a central location". 
The six projects of the campaign considered above were carried out in logic sequence to achieve the largest effect. At first by means of "Media Service" project they created the basis for coverage of the campaign and all aspects of Germany life in the media. The fan club formation and 365 landmarks in the land of ideas competition allowed to involve the population in the campaign that in turn provided support to campaign events within the country. Creation of sculptures attracted many tourists and attention of the media on the eve of the World Cup carrying out. Since March 2006 the sculptures and the 100 masterminds of the country exhibition reflected a huge scientific heritage and potential of the country. After the demonstrated wealth of ideas, its logical conclusion was the advertising campaign calling on the eve of the World Cup to visit Germany and to make investments.

The image campaign results:

- the most popular in the history of Germany image campaign attracted the audience of over 3,5 billion people;

- as of July 14, 2006, in Germany there appeared about 14200 articles regarding the campaign;

- the campaign initially planned to be over at the end of 2006, was prolonged till 2010;

- 22 large German companies became partners of the campaign (on the site in "Partners" section one can see innovative achievements and workings out of each of them);

- journalists mentioned, that after the World Cup end there were two winners - Italy and Germany as Germany could improve its image both within the country and abroad;

- according to the research, after carrying out of the campaign the majority of Germans perceived their country as progressive, cosmopolitan, inventive and innovative.

From experience of carrying out of the campaign to strengthen the image of Germany it is possible to make following conclusions:

1. Carrying out of image improvement campaign is better to time to the large international event which will automatically draw mass media attention.

2. Only joint actions of a society and the state will be able to provide the campaign with resources and population support.
3. The constant presence of the higher officials of the state at the key events ensures the media attention and emphasizes true interest of the state in solving the problem.

4. Provision of mass media with any social, economic, cultural information ensures wider distribution of the central campaign idea.

5. At image improvement campaign its every detail should act to inform address groups about the key idea (projects showed innovation ability, scientific potential and uniqueness of Germany)

6. The campaign should not be sporadic - it is necessary to create information occasions all the time.

7. The unconventional approach to boring topics - the campaign guarantee of success (posters with model Claudia Schiffer).

Germany image strengthening campaign was integrated organization of a large number of events that touched on about 3,5 billion. people.

\section{POSSIBILITIES AND PROSPECTS OF KAZAKHSTAN NATIONAL BRANDING}

The German image campaign experience described above may be used by Kazakhstan for working out of its own image campaign. Kazakhstan has time and possibility to do corresponding work before carrying out of 2017 University Games and EXPO 2017 which will ensure attention from mass media, the inflow of tourists from all over the world. The involving of the private sector in image campaign will favor civil society activation and will unite the country. Thus, Kazakhstan may use all those tools which allowed Germany to score success: to involve young scientists, to tell about conducted workings out dealing with exhibition topics, to regularly give information on current events to the media, to create special body which would be engaged in solution of image problems, to use famous people for an advertising campaign.

Concerning our country "Kazakhstan - heart of Eurasia" project, put forward as image generating idea, may provide ample opportunities for realization of dozens of new subprojects, covering all regions, cities and population strata. And these projects may be as innovative (containing the key idea of the EXPO-2017 "Energy of the future"), as 
historical and cultural. 2017 Winter University Games with "Spread your wings" slogan will present to the world Kazakhstan as the country with athletic, creative young people directed to scientific knowledge. Along with today's innovations, it is appropriate to remind of those innovations that ancestors who lived in ancient Steppe of Kazakhstan gave to world civilization. On the one hand, one can remember the contribution to civilization development made by Kazakh ancestors (horse domestication, invention of boots, breeches, saddle, stirrups, horse harness, ancient monuments of writing, yurt, urban civilization on Syr-Darya banks, musical instruments of Desht-i-Kypchak steppe - kobyz and dombra, teacher of mankind Abu Nasr alFarabi, the second Mecca of the Islamic world Turkestan with Hodzha Ahmet Yassaui mausoleum, Saks barrows and "Golden Warrior", Berelsky barrows, khan headquarters in Burabay, etc.) It will remind tourists, that, where present Astana is located once, there was an ancient steppe settlement "Bozok" (Blue Arrow) where headquarters of Kypchak khans was situated. Here it cries out for the analogy to the monuments of innovative football boots, printing, etc. of "Walk of Ideas" in the capital of Germany.

The exhibition will acquaint the world with multinational culture, ancient history, art, traditions and hospitality of Kazakhstani people, will increase recognizability and tourist appeal of Kazakhstan in the world community.

The result of carrying out of world exhibitions is an expansion of the international, economic, political, cultural and scientific contacts. Carrying out of "Expo 2017" - the big step toward the establishment of Kazakhstan as international exhibition and information and presentation platform. For EXPO 2017 not only in Astana but also in different regions of the country there will be prepared and constructed attractive tourists' objects.

For example, in Akmolinsk area, one will construct "Ethno-aul" cultural and tourist complex surrounded by an eco-settlement consisting of 100 dwellings. During construction, they will use only ecologically clean construction materials and "green" technologies - everything according to "Energy of the future" EXPO theme (n.d., 2013). It is interesting, that during the EXPO Kazakhstan it is planned to promote one of the key ideas of the President of the country N. Nazarbayev about the transition to "green economy". He often says that transition process to the environment-friendly economy will be accompanied by serious changes in several branches, it will generate new industry and will create qualitative workplaces. And this is idea for an exhibition which will draw hundreds of thousands of tourists to visit it, specially constructed objects or those that are already in operation on industrial scale in different regions of the country (wind generators, large and small hydroelectric power plants in Almaty and East Kazakhstan oblasts, solar batteries in southern regions, etc.) The pride that such a grand event takes place on Kazakhstan soil, will produce patriotic sentiments upsurge of the country citizens.

To hold the Winter University Games in Almaty in 2017 is an ideal possibility in order to show to the world amenities of the Republic of Kazakhstan. Sunkar eyes have become the mascot of the University Games. "Free and strong indigenous inhabitant of Kazakh steppes, it always defeats its enemies, often surpassing it by their sizes", - it is like this that developers positioned their eyes. The falcon quite corresponds to the Kazakh people spirit. The mascot to disclose the key concept of "Spread your wings!" slogan, is shown in the form of stylized wings.

It is necessary to consider for the attraction of tourists that factor too that from the organization and carrying out level (brightness, spectacularity, and hospitality) of the University Games which will take place during the winter period, on the eve of EXPO-2017. Organizers of the winter games should make so that they ensure full house of tourists at the second visit of the country during the summer period.

Each city of Kazakhstan may contribute its mite to formation of image and national brand promotion, proceeding from its peculiarities and achievement of today (Baikonur - space harbor, Karaganda industry center and scientific intelligentsia city, Aktau - city of oil industry workers and the center of ancient Mangyshlak, Shymkent, Taraz - cities on the ancient Silk way, Kurchatov - scientific center of nuclear test on the soil of Kazakhs, channel in Sary-Arka steppe "Irtysh-Karaganda" and so on). In Astana, there is already a realized 
project like "Walks of Ideas in Germany" in the form of an ethnic-memorial complex "Map of Kazakhstan - Atameken" or "Kazakhstan in miniature". Near it, there may be sculptural compositions and operating copies of objects devoted to innovative ideas, arisen on the Kazakh soil at the dawn of a human civilization (domesticated horses, bullock cart, yurt, breeches, saddle, stirrups etc.). Ethno-auls and agrotourism complexes may and should be created also around such cities as Kokshetau, Karaganda, and Pavlodar. They will become centers to demonstrate and hold various events according to national traditions within reach of Astana. It is necessary to note, what even without state support some entrepreneurs began to create agro - and ethno-tourism objects in the mentioned cities. For example, $5 \mathrm{~km}$ from Karaganda "Kamila" farm by itself and using its own means began to create an agritourism complex. Some scientists and students of the Karaganda Economical University of Kazpotrebsoyuz were taking an active part in designing of the given complex. The complex includes riding hall and stables, falcon, quail and pheasant farms, stocked pond and a pond for beach rest, a cafe building, a complex of guest cabins with all conveniences, racecourse, model farms for keeping of cows, sheep, goats, camels and other animals. They will serve for child-rearing of townspeople and will teach to look after "their own" animals (each child will have an interim certificate on the right of possession of a kid, a lamb, a chicken and so on). Near farms there will be beds for the cultivation of vegetables, berries, fruit trees will be planted. They also become available to visitors where right from a bed, parents with children can see and learn how they grow, gather a bunch of radishes, of spring onions, dill, and other garden stuff, pick berries and fruit. Wind-generated installations will give the possibility to satisfy partly the complex need in the electric power.

By the time of carrying out of the EXPO-2017 at a racecourse championship of teams of the country regions and ones from abroad for such games as "Kokpar", "Alaman baiga", "Kyz kuu", and also for individual ones as "Zhamby atu (sadak tartu)", "Oramal ilu" trick riding, "Tal shabu", "Falconry", etc. May take place. Such an approach organized in each of the regions, along with well-planned marketing strategy will draw the attention of tourists and will give a charge for national spirit upsurge of the people of Kazakhstan. "Kamila" agro-tour complex project provides for the possibility to carry out, near "Ethno-aul" by the population request, national weddings, solemn events - "as beru" initiation, "Kyz uzatu" (decorated horse wagons - in summer, in winter - troika sleigh) etc. Unlike exhibition model complexes of temporary nature, the given complex is designed as actually functioning and where there is an actual life with all attributes during the whole year. Such complexes, with support from the state in the form of loans and preferences, become a considerable contribution to international image strengthening and to the Kazakhstan entry into 30 most developed countries.

\section{WORKS CITED}

Anholt, S. (2007). Competitive Identity: The New Brand Management for Nations, Cities, and Regions (1st ed.). Palgrave Macmillan. Retrieved from http://www.lib.tpu.ru/fulltext/c/2013/C20/029.pdf

Anholt, S. (2008). Editorial: Place branding: Is it marketing, or isn't it? Place branding and Public Diplomacy, 4, 1-6. Retrieved from http://www.lib.tpu.ru/fulltext/c/2013/C20/029. pdf

Ashworth, G., \& Kavaratzis, M. (2010). Towards effective place brand management: Branding European cities and regions. Cheltenham, UK: Edward Elgar Publishing Limited.

Bodriyyar, Z. (1995). Sistema veshchey. Moscow.

Kotler, P., Haider, D., \& Rein, I. (2002). Marketing Places: Attracting Investment, Industry, and Tourism to Cities, States, and Nations. NY: The Free Press.

Kudasheva, L. (2013). Prodvizheniye gorodskoy destinatsii na osnove korntseptsii brendinga mest. Retrieved from http://www.lib.tpu.ru/fulltext/c/2013/C20/029.pdf

Kuryatov, V. (2014, Jun 05). Po marshrutam Shelkovogo Puti. Kazakhstanskaya pravda(109). Retrieved from http://www.kazpravda.kz/pdf/05062014012853.pdf 
n.d. (2013, Sep 13). V ramkakh "EKSPO-2017" v Akmolinskoy oblasti postroyat etnoauly. Retrieved from Karavan: http://news.gazeta.kz/art.asp?aid=386061

n.d. (2016). Imidzh strany: Germaniya. Retrieved from Imagebelarus.by: http://imagebelarus.by/node/83376

Nazarbayev, N. (2006, Jan 18). Strategiya vkhozhdeniya Kazakhstana v chislo 50 naiboleye konkurentosposobnykh stran mira. Retrieved from Adilet: http://adilet.zan.kz/rus/docs/K060002006_\#z0

Nazarbayev, N. (2012, Dec 14). Strategiya "Kazakhstan-2050": novyy politicheskiy kurs sostoyavshegosya gosudarstva. Retrieved from Ofitsial'nyy sayt Prezidenta Respubliki Kazakhstan: http://www.akorda.kz/ru/addresses/addresses_of_president/page_poslanieprezidenta-respubliki-kazakhstan-n-nazarbaeva-narodu-kazakhstana-14-dekabrya-2012g_1357813742

Posypanova, O. (2012). Ekonomicheskaya psikhologiya: psikhologicheskiye aspekty povedeniya potrebiteley - Monografiya. Kaluga: KGU im. K.E. Tsiolkovskogo.

Received for publication:

10.03.2016

Revision received:

01.06 .2016

Accepted for publication:

12.12.2016

\section{How to cite this article?}

Style - APA Sixth Edition:

Borbasova, Z., Ulakov, S., \& Ossik, Y. (2017, Jan 15). Image and nation brand formation as tourism development factor in Kazakhstan. (Z. Cekerevac, Ed.) MEST Journal, 5(1), 10-21. doi:10.12709/mest.05.05.01.02

Style - Chicago Sixteenth Edition:

Borbasova, Ziada, Sairan Ulakov, and Yuri Ossik. "Image and nation brand formation as tourism development factor in Kazakhstan." Edited by Zoran Cekerevac. MEST Journal (MESTE) 5, no. 1 (Jan 2017): 10-21. doi:10.12709/mest.05.05.01.02.

Style - GOST Name Sort:

Borbasova Ziada, Ulakov Sairan and Ossik Yuri Image and nation brand formation as tourism development factor in Kazakhstan [Journal] // MEST Journal/ ed. Cekerevac Zoran. - Belgrade Toronto : MESTE, Jan 15, 2017. - 1 : Vol. 5. - pp. 10-21.

Style - Harvard Anglia:

Borbasova, Z., Ulakov, S. \& Ossik, Y., 2017. Image and nation brand formation as tourism development factor in Kazakhstan. MEST Journal, 15 Jan, 5(1), pp. 10-21.

Style - ISO 690 Numerical Reference:

Image and nation brand formation as tourism development factor in Kazakhstan. Borbasova, Ziada, Ulakov, Sairan and Ossik, Yuri. [ed.] Zoran Cekerevac. 1, Belgrade - Toronto : MESTE, Jan 15, 2017, MEST Journal, Vol. 5, pp. 10-21. 